Кірпічніков Ю. А., канд. техн. наук (ORCID: 0000-0001-6893-3569);

Литовченко Г. Д. $\quad$ (ORCID: 0000-0002-8625-1438);

Розумний О. Д.

Самойленко Н. М

(ORCID: 0000-0003-3225-8375);

(ORCID:0000-0002-9432-4465).

Центр воєнно-стратегічних досліджень Національного університету оборони України імені Івана Черняховського, Київ

\title{
Підходи до технологічної підтримки інформаційної інфраструктури Міністерства оборони України
}

\begin{abstract}
Резюме. Стаття присвячена узагальненню та систематизації особливостей підходів до технологічної підтримки14 інформаційних систем на прикладі рекомендацій методології Control Objectives for Information and related Technology (CobIT). У результаті проведеного дослідження запропоновано підходи щодо організації служби технологічної підтримки інформаційної інфраструктури Міністерства оборони України на основі застосування кращих світових практик.

Ключові слова: інформаційна інфраструктура; управління IT-послугами; служба Service Desk.
\end{abstract}

Постановка проблеми. Існуючі міжнародні стандарти в галузі інформаційних технологій (IT) рекомендують роглядати інформаційну інфраструктуру будь якої організації 3 погляду сукупності інформаційних систем (IC), що забезпечують автоматизацію їі функціональних процесів для надання якісних IT-послуг [1-4].

Метою створення інформаційної інфраструктури Міністерства оборони України є підвищення ефективності прийняття управлінських рішень керівним складом, через забезпечення посадових осіб (користувачів IC) необхідним рівнем інформаційних сервісів для надання своєчасної, достовірної, повної та несуперечливої інформації щодо стану процесів управління оборонними ресурсами та Збройними Силами України.

У зв'язку з наявними проблемами, що пов'язані 3 необхідністю розвитку існуючої інформаційної інфраструктури на основі сучасних підходів, питання технологічної підтримки інформаційної інфраструктури Міністерства оборони України є актуальними.

Аналіз останніх досліджень і публікацій. Задачі технологічної підтримки виникли 3 появою в структурі організацій і установ ще перших IC. Для забезпечення їx функціонування використовувався так званий технологічний підхід, суть якого полягає в підтримці працездатності апаратного і програмного забезпечення (ПЗ) окремих IC.

3 розвитком IT i широким впровадженням великої кількості різних IC у діяльність організацій i установ, фокус технологічної підтримки окремих IC змістився на надання користувачам певного набору функціональності IC як IT-послуги.

Цей підхід отримав назву управління ITпослугами - Information Technology Service Management (ITSM), який зосереджений на оптимальному використанні поєднання персоналу та ІТ-процесів [5]. На відміну від технологічного підходу, ITSM рекомендує зосередитися на послугах, що надаються користувачам, а не на самих технологіях. Сучасні підходи ITSM, грунтуючись на міжнародних стандартах i кращих практиках в цій галузі, орієнтовані на задоволення потреб користувачів в IT-послугах за допомогою створення, так званої ІТ-служби, у функції якої входить технологічна підтримка інформаційної інфраструктури.

Одним 3 відомих підходів до управління корпоративними інформаційними технологіями на основі ITSM, який допомагає визначити стратегію організації IT-служби, забезпечити взаємодію 3 користувачами - $\epsilon$ методологія CobIT (Control Objectives for Information and related Technology) [6-8]. Методологія CobIT розроблена ISACF (Фонд аудиту і контролю інформаційних систем) та підтримується міжнародною асоціацією ISACA (Асоціація аудиту і контролю інформаційних систем), яка займається освітою та сертифікацією в галузі забезпечення якості та безпеки IC [9].

Методологія CobIT нині $€$ синтезом майже чотирьох десятків міжнародних стандартів у галузі аудиту, контролю, управління інформаційними технологіями та інформаційної безпеки, таких як стандарти серій ISO 9000, ISO 10000, ISO 27000 тощо. Ïї стратегічним завданням $\epsilon$ ліквідація розриву між керівною ланкою організації з їі баченням 
цільової спрямованості своєї діяльності та діяльності IT-служби, яка здійснює підтримку інформаційної інфраструктури.

Метою статті с аналіз підходів щодо створення служби технологічної підтримки інформаційної інфраструктури Міністерства оборони України на основі рекомендацій методологіï CobIT.

Виклад основного матеріалу. Методологія CobIT рекомендує механізми управління та аудиту IC, що засновані на кращому практичному досвіді побудови i вдосконалення інформаційних процесів у різних організаціях i установах. Основу моделей, що застосовуються CobIT, становлять процеси, розроблені на основі методик i стандартів аудиту IC від різних виробників програмно-апаратних засобів.

Згідно 3 CobIT, процес - це дія, що спрямована на досягнення результату за умови оптимального використання ресурсів, яка може коригуватися під час iї виконання. Усі ресурси, задіяні в процесі, структуруються таким чином, щоб максимально ефективно виконувати цей процес. Ці процеси стабільні та рідко змінюються, порівняно 3 організаційними об’єктами (співробітники, відділи, департаменти та ін.).

CobIT охоплює усі IT-процеси, які згруповані за такими напрямами:

планування та організація - група процесів, які визначають напрями щодо впровадження рішень і забезпечення ITсервісів;

придбання i впровадження - група процесів, які забезпечують впровадження рішень і надання на їх основі IT-сервісів;

експлуатація та супровід - група процесів, що представляють самі рішення i роблять їх доступними для кінцевих користувачів;

моніторинг - група процесів, що виконують нагляд за всіма IT-процесами для того, щоб переконатися в просуванні у правильному напрямку.

Особливістю підходу CobIT відносно інших підходів ITSM є присутність у ньому моделі зрілості спроможностей (Capability Maturity Model) інформаційної інфраструктури, яку пізніше замінила модель оцінки процесів (CobIT Process Assessment Model, PAM). В основі моделей лежить шкала ISO/IEC 15504 оцінки спроможностей:

рівень 0: процес неповний (Incomplete) процес ще не впроваджений або не здатний відповідати своєму призначенню; рівень 1: процес

здійснюється

(Performed) - процес впроваджений і відповідає своєму призначенню. У разі якщо результати процесу не досягаються, то такий процес буде оцінений на 0 (нуль);

рівень 2: процес керований (Managed) процес попереднього рівня здійснюється керовано (тобто планується, відстежується і коректується). Створюються, контролюються і підтримуються робочі продукти (результати) процсу;

рівень 3: процес

встановлений

(Established) - керований процес здатний отримувати очікувані результати (outcomes) однаково виконується во всій організації, відповідно до загальних правил;

рівень 4: процес передбачуваний (Predictable) - встановлений процес тепер отримує результати в умовах заданих обмежень, є можливість передбачити обсяг досягнення цілей процесу в заданих обмеженнях;

рівень 5: процес оптимізуємий (Optimizing) - передбачуваний процес тепер постійно вдосконалюється, щоб досягати поточних і майбутніх цілей організації.

Використання моделі РАМ робить цей підхід найефективнішим для визначення цілей в галузі IT, побудови системи збалансованих показників для IT-служби і проведення внутрішніх i зовнішніх аудитів. На підставі результатів оцінювання процесів за рівнями зрілості можливо сформувати заходи щодо вдосконалення ІТ-процесів.

Усі ресурси, що є об'єктами контролю, оцінюються 3 погляду їх відповідності критеріям, які логічно випливають із завдань організації: ефективність, технічний рівень, безпека, цілісність, придатність, узгодженість, надійність. Для кількісної та якісної оцінки за цими критеріями широко використовується порівняння 3 кращими світовими показниками, що забезпечує повну, об'єктивну та актуальну інформацію про поточний стан інформаційної інфраструктури, можливі рішення щодо зміни ситуації, перспективи та ризики їх реалізації.

Отже, відбувається зміщення акцентів в управлінні інформаційною інфраструктурою, пов'язаних 3 тим, що фактично підрозділи організації споживають не окремі IC, a ITпослуги, оцінка яких має проводитися не тільки за наданою функціональністю, але і за якістю обслуговування. До того ж серйозно змінюється модель управління інформаційною інфраструктурою - об'єктом управління стає послуга, a не сама інформаційна інфраструктура, метою - рішення поставлених 
завдань, а не забезпечення технічних можливостей.

Основні відмінності управління ITпослугами від управління окремими $\mathrm{IC}$ полягають у такому:

користувачі формулюють вимоги до ITпослуг, а ІТ-служба забезпечує їх реалізацію;

інформаційні системи для IT-служби мають статус ресурсу;

результати роботи IT-служби можуть визначатися фінансовими показниками: витрати по розробленню, впровадженню i супроводу IT-послуг;

контроль діяльності IT-служби здійснюється на основі показників, що мають цінність 3 позицій користувачів;

прозорість діяльності IT-служби забезпечується через формалізацію управлінських процедур у вигляді пакету документів, які є нормативною базою для всіх IT-процесів.

Для швидкого i якісного розв'язання проблем 3 наданням IT-послуг необхідно визначити єдину точку контакту користувачів 3 фахівцями IT-служби, яка складається із співробітників, що спеціалізуються в різних областях інформаційних технологій - від навчання користувачів основам використання прикладного ПЗ до надання технологічної підтримки. Основне призначення технологічної підтримки - оперативне розв'язання проблем користувачів за допомогою оформлення відповідних заявок та гарантованого їх відпрацьювання у відведені терміни.

Існують різні способи надання технологічної підтримки: телефоном, електронною поштою, через спеціалізовані онлайн-сервіси або за допомогою інших інструментів, у яких користувачі можуть реєструвати заявки (інциденти) і отримувати зворотний зв'язок на кожному 3 етапів їх обробки. Системи такого класу, зазвичай називають Help Desk (с англ. - стіл допомоги) або Service Desk (с англ. - стіл послуги). Прийнято вважати, що термін Service Desk є більш загальним і відрізняється від Help Desk тим, що зачіпає значну область діяльності ITслужби, тоді як під Help Desk розуміється лише управління заявками користувачів.

Для користувачів Service Desk виступає за центральну точку контакту з IT-службою, що гарантує їм своєчасне, а головне якісне розв'язання проблем. Завдяки Service Desk користувачам немає необхідності витрачати час на пошуки фахівців, які зможуть розв'язати їх проблеми. IT-служба за допомогою Service Desk може вирішувати значну частину типових заявок користувачів, що дасть змогу не залучати досвідченіших фахівців.

Крім цього, у функції Service Desk входить збір інформації та інформування користувачів про події $\mathrm{i}$ можливості, які можуть впливати на здійснення користувачами своєї повсякденної діяльності. Service Desk також може бути центром прийому запитів на зміни ПЗ, а також повідомлення користувачів про внесення цих змін, забезпечення надійності обслуговування критично важливих систем, таких як маршрутизатори, сервери, шлюзи, програми та бази даних.

Основні переваги Service Desk для організації служби технологічної підтримки полягають у:

підвищенні якості обслуговування користувачів, поліпшенні сприйняття ITпослуг користувачами;

поліпшенні якості обробки запитів користувачів;

скороченні часу реагування на заявку користувачів;

підвищенні доступності обслуговування завдяки єдиній точці контакту, спілкування i отримання інформаціі; використанні попереджувального підходу до надання послуг; зменшенні негативного впливу на бізнес; отриманні контролю над інфраструктурою.

П3, що забезпечує роботу Service Desk, має включає такі елементи:

базу даних для обліку заявок;

інтерфейс для реєстрації нових заявок користувачами;

центр обробки заявок;

оповіщення, своєчасно інформують користувача про статус заявки;

базу знань, що описує вже знайомі ситуації і способи їх вирішення.

Планування, реєстрація, класифікація, тестування, оцінка змін дає змогу значно знизити негативні впливи змін на якість надання IT-сервісів. Питання щодо надання ITпослуг, обробки запитів користувачів, технічного забезпечення процесів, впровадження нових IC, ефективного використовування ресурсів на окремих місцях $\epsilon$ найпроблемнішими зонами, за які відповідають фахівці служби технологічної підтримки.

Такій підхід до організації служби Service Desk забезпечує: 
підтримки;

єдину точку контакту до служби

стандартний спосіб реєстрації і видачі завдань фахівцям;

контроль над послідовністю виконаних

робіт, витраченого часу і ресурсів;

призначення пріоритетів запитам

залежно від типу запиту, конкретного користувача або інших обставин;

зберігання бази знань за минулими запитами, що дає змогу фахівцям швидко розв’язувати проблеми, схожі з тими, що вже виникали.

Впровадження підходів CobIT i створення в структурі служби технічної підтримки Service Desk дають змогу отримати такі переваги:

скорочення періоду обслуговування запитів користувачів щодо вирішення інцидентів;

ведення історії запитів користувачів; доступність інформації щодо інциденту для всього персоналу служби підтримки;

удосконаленя процедур відстеження, ескалації та обробки інцидентів;

доступність в оперативному режимі інформації щодо відомих помилок та рішень, усунення втрат і дублювання інформації;

якісніше використання кваліфікованого персоналу.

Отже, на основі проведеного аналізу, як основні функції служби технологічної підтримки інформаційної інфраструктури Міністерства оборони України можна визначити:

організацію розгортання IC, а також необхідних комплектуючих, розхідних матеріалів, П3, розроблення переліку та плану закупівель обладнання, співпрацю 3 його постачальниками;

забезпечення

функціонування

корпоративної телекомунікаційної мережі;

$\mathrm{IC}$; встановлення та впровадження нових

тестування, технічне обслуговування та постійне супроводження використовуємих IC, підтримання на сучасному рівні обладнання та П3;

организацію ремонту техніки та оновлення ПЗ;

розвиток, технічне обслуговування мережевої інфраструктури;

системне адміністрування, резервування i відновлення даних, зокрема підготовку i зберігання резервних копій;

розроблення та реалізацію політики та стратегії інформаційної безпеки; консультації, навчання та постійний контроль користувачів;

разроблення, узгодження та затвердження внутрішньої нормативної та регламентуючої документації у галузі використання, супроводження, оновлення інформаційної інфраструктури;

забезпечення своєчасної інвентаризації та списання техніки і ПЗ, виконання ліцензійних угод щодо використання П3;

підтримку актуального антивірусного захисту всередині корпоративної мережі; підготовку звітів у галузі інформаційної інфраструктури; забезпечення виконання вимог законодавства держави в галузі інформаційних технологій та захисту інформації.

Висновки. Методологія CobIT надає детальні вказівки щодо впровадження ITпроцесів і $€$ еталонною моделлю щодо організації управління інформаційною інфраструктурою, відповідно до кращих світових практик. Рекомендації CobIT доцільно використати для опису складу та логіки процесів служби технологічної підтримки інформаційної інфраструктури Міністерства оборони України, які повинні виконуватися для забезпечення надання оптимального рівня сервісів споживачам IT-послуг.

Такий підхід засновано на наступному основоположному принципі: для того щоб керівництво Міністерства оборони України забезпечило себе належною $\mathrm{i}$ релевантною інформацією, необхідною для досягнення цільових установок, воно повинно інвестувати в інформаційну інфраструктуру та управляти нею за допомогою структурованого комплексу процесів.

\section{СПИСОК ВИКОРИСТАНОЇ ЛИТЕРАТУРИ}

1. Системи управління якістю. Основні положення та словник термінів. (ISO 9000:2005, IDT): ДСТУ ISO 9000 : 2007. [Чинний від 2008-01-01]. К. : Держспоживстандарт України, 2008. 29 с. (Національний стандарт України).

2. Системи управління якістю. Вимоги (ISO 9001:2008, IDT): ДСТУ ISO 9001 : 2009. [Чинний від 2009-09-01]. К. : Держспоживстандарт України, 2009. 26 с. (Національний стандарт України).

3. Управління задля досягнення сталого успіху організації. Підхід на основі управління якістю (ISO 9004: 2009, IDT) : ДСТУ ISO 9004:2012. [Чинний від 2012-11-28] К. : Держспоживстандарт України, 2012. 29 с. (Національний стандарт України).

4. ISO /DIS 9001:2015 (DraftInternationalStandard)// Офіційний веб-сайт ISO. Режим доступу: 
http://www.iso.opg/iso/iso_catalogue/catalogue_ics. htm.

5. Bahrain Government Embraces COBIT 5 Governance and IT Management By Harikrishnan Sugumaran, ITIL, ToGAF, Khalid Al-Mutawah, Ph.D., Zakareya Ahmed Al-Khaja, Ph.D. [Electronic Resource]. Mode of access: http://www.isaca.org/COBIT/focus/Pages/bahraingovernment-embraces-cobit-5-governance-and-itmanagement.aspx.

6. COBIT 5: Creating Buy-in and Empowering Teams to Change By Paul Wilkinson and Gary Hardy [Electronic Resource]. Mode of access: http://www.isaca.org/COBIT/focus/Pages/cobit-5creating-buy-in-and-empowering-teams-tochange.aspx.

7. Dubai Customs COBIT 5 Implementation By Vishal Vyas, GEIT, Juma Al Ghaith, Ahmad Al
Yaqoobi, PMP, and Syed Junaid Hasan, PMP [Electronic Resource]. Mode of access: http://www.isaca.org/COBIT/focus/ Pages/dubaicustoms-cobit-5-implementation.aspx.

8. Initiating GEIT Using COBIT 5 at the Oman Ministry of Manpower By Rohit Banerjee, CGEIT, COBIT 5 Implementation, ISO/IEC 38500 Lead IT Corporate Governance Manager, ISO 9001 LA \& LI, ITIL V3 2011 Foundation, MSP Registered Practitioner, PMP, PRINCE2 Registered Practitioner, Six Sigma Black Belt; Redha Ahmed Al-Lawati, C|CISO, DCES, DCIS, DCOM, ISO/IEC 27001 LA; and Maqbool Mohammed Al-Balushi, CCNA, CEH, CISSP, ISO/IEC 27001 LA, MSCE. [Electronic Resource]. Mode of access: http://www.isaca.org/COBIT/focus/Pages/initiatinggeit-using-cobit-5-at-the-oman-ministry-ofmanpower.aspx.

Стаття надійшла до редакційної колегії 22.02.2019

Кирпичников Ю. А., канд. техн. наук;

Литовченко А. Д.;

Розумний О. Д;

Самойленко Н. Н.

Центр военно-стратегических исследований Национального университета обороны Украины имени Ивана Черняховского, Киев

\section{Подходы к технологической поддержки информационной инфраструктуры Министерства обороны Украины}

Резюме. Статья посвящена обобщению и систематизации особенностей подходов к технологической поддержке информационных систем на примере рекомендаций методологии СоbIT. В результате проведенного исследования предложены подходы к организации службы технологической поддержки информационной инфраструктуры Министерства обороны Украины на основе применения лучших мировых практик.

Ключевые слова: информационная инфраструктура; ИТ-услуги; CobIT; Service Desk.

\section{Y. Kirpichnikov, PhD (Technical);}

\section{A. Litovchenko; \\ O. Rozumnij; \\ N. Samoilenko}

Center for Military and Strategic Studies of the National Defense University of Ukraine named after Ivan Cherniakhovskyi, Kyiv

\section{Approaches to the technological support of the information infrastructure of the Ministry of Defense of Ukraine}

Resume. The article is devoted to the generalization and systematization of the features of approaches to the technological support of information systems using the recommendations of the CobIT methodology as an example. As a result of the study, approaches to the organization of a technological support service for the information infrastructure of the Ministry of Defense of Ukraine based on the application of best international practices are proposed.

Keywords: information infrastructure; IT services CobIT; Service Desk. 